\title{
Reversible cursive agraphia
}

Figure 1 Patient's handwriting on 3 different occasions
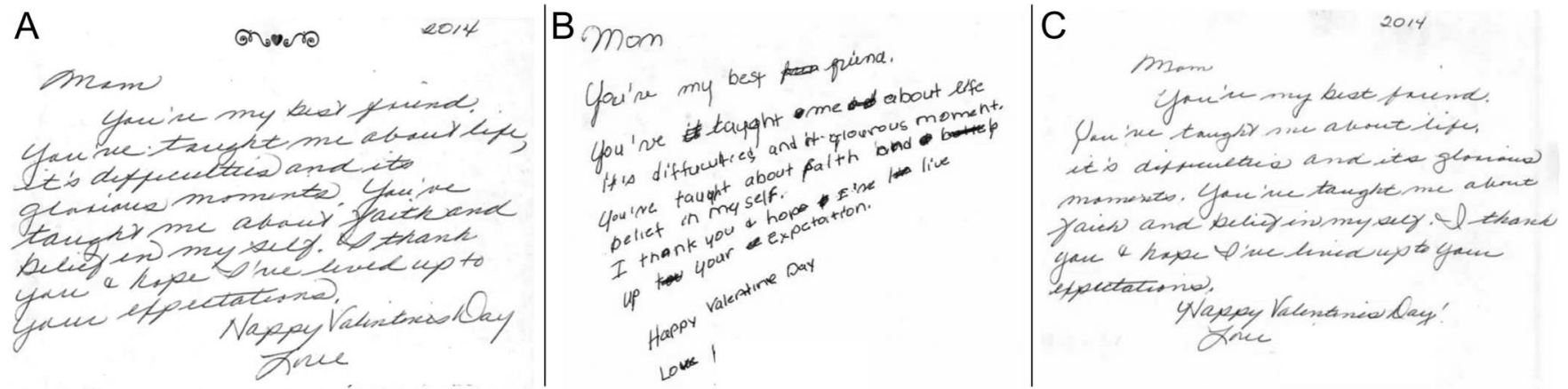

Valentine's card handwritten by the patient (A) 1 month prior to presentation, (B) a handwritten copy produced by the patient at the time of presentation (after being asked to use her normal cursive handwriting), and (C) 5 days after resection of the skull-based metastasis.

Figure 2 Brain MRI
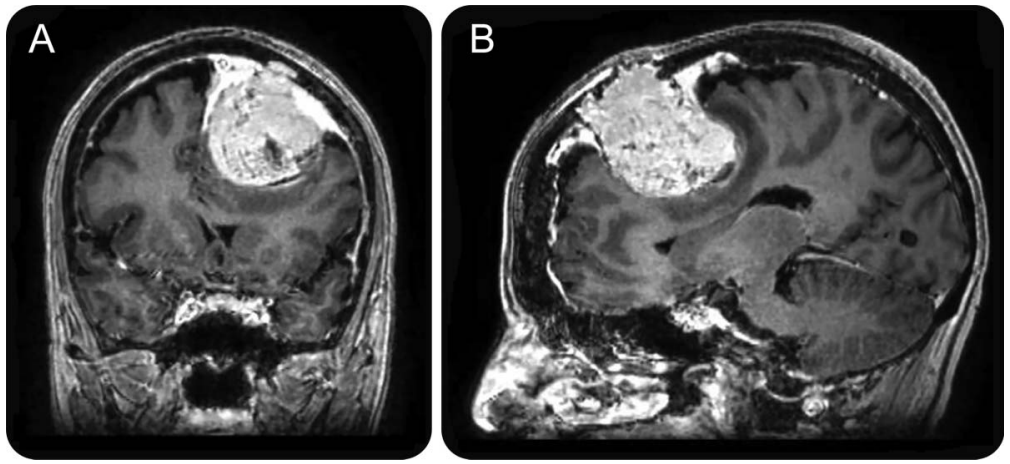

(A) Axial and (B) sagittal brain MRI, postgadolinium spoiled gradient recalled echo sequence, shows a large, enhancing calvarial lesion, exerting mass effect on left frontal lobe.

A 56-year-old right-handed woman, with fine penmanship, presented with inability to perform cursive writing due to calvarial metastasis of a tibial osteosarcoma and left frontal lobe involvement (figures 1 and 2). Tumor resection resulted in a regained capacity for cursive handwriting. Allographs are variants of graphemic representations (upper vs lower case or cursive vs print). Writing requires activation of abstract graphemic representations, selection of the allograph, and formulation of a motor plan. ${ }^{1}$ Allographic agraphia is rare, affecting the second or third of these processes, differing from other forms of nonaphasic agraphia such as apraxia or visuospatial agraphias. ${ }^{2}$ It has been associated with left frontal lesions in clinical and imaging studies. ${ }^{2,3}$

Marcelo Matiello, MD, MSc, Eli Zimmerman, MD, David Caplan, MD, Adam B. Cohen, MD

From the Department of Neurology, Harvard Medical School, Massachusetts General Hospital, Boston.

Author contributions: Marcelo Matiello: drafting/revising the manuscript, study concept or design, analysis or interpretation of data, accepts responsibility for conduct of research and final approval. Eli E. Zimmerman: drafting/revising the manuscript, study concept or design, analysis or interpretation of data, accepts responsibility for conduct of research and final approval. David Caplan: analysis or interpretation of data, accepts responsibility for conduct of research and final approval. Adam Cohen: drafting/revising the manuscript, study concept or design, analysis or interpretation of data, accepts responsibility for conduct of research and final approval, acquisition of data, study supervision. 
1. Rapp B, Caramazza A. From graphemes to abstract letter shapes: levels of representation in written spelling. J Exp Psychol Hum Percept Perform 1997;23:1130-1152.

2. Menichelli A, Machetta F, Zadini A, Semenza C. Allographic agraphia for single letters. Behav Neurol 2012;25:233-244.

3. Planton S, Jucla M, Roux FE, Démonet JF. The "handwriting brain": a meta-analysis of neuroimaging studies of motor versus orthographic processes. Cortex 2013;49:2772-2287.

\section{Get Connected. Stay Connected.}

Connect with the American Academy of Neurology's popular social media channels to stay up-todate on the latest news and breakthroughs in neurology, and network with peers and neurology thought leaders. Visit AAN.com/Connect.

\section{Quality CME. Expert Faculty. Improved Patient Care.}

\section{Register Today for the AAN Fall Conference!}

Register today for the 2015 AAN Fall Conference, set for October 16 through 18 at The Cosmopolitan of Las Vegas. Learn from expert faculty as they present the latest clinical and practice management advances to help you stay current, provide the best patient care, and keep your practice thriving-all while earning up to 18.75 CME in three days! New for 2015-four courses now qualify for self-assessment (SA) CME (get up to $15 \mathrm{SA}$ credits total).

Early registration and hotel discounts end September 10. Visit AAN.com/view/Fall to learn more and register today.

\section{Save These Dates for AAN CME Opportunities!}

Mark these dates on your calendar for exciting continuing education conferences by the American Academy of Neurology. Learn more at AAN.com/conferences.

\section{Sports Concussion Conference}

- July 24-26, 2015, Denver, Colorado, Colorado Convention Center

\section{AAN Fall Conference}

- October 16-18, 2015, Las Vegas, NV, The Cosmopolitan of Las Vegas

AAN Annual Meeting

- April 15-21, 2016, Vancouver, BC, Canada, Vancouver Convention Centre 


\title{
Neurology
}

\author{
Reversible cursive agraphia \\ Marcelo Matiello, Eli Zimmerman, David Caplan, et al. \\ Neurology 2015;85;295-296 \\ DOI 10.1212/WNL.0000000000001754
}

This information is current as of July 20, 2015

\section{Updated Information \& Services}

References

Subspecialty Collections

Permissions \& Licensing

Reprints including high resolution figures, can be found at: http://n.neurology.org/content/85/3/295.full

This article cites 3 articles, 0 of which you can access for free at: http://n.neurology.org/content/85/3/295.full\#ref-list-1

This article, along with others on similar topics, appears in the following collection(s):

Executive function

http://n.neurology.org/cgi/collection/executive_function

Metastatic tumor

http://n.neurology.org/cgi/collection/metastatic_tumor

MRI

http://n.neurology.org/cgi/collection/mri

Information about reproducing this article in parts (figures,tables) or in its entirety can be found online at:

http://www.neurology.org/about/about_the_journal\#permissions

Information about ordering reprints can be found online:

http://n.neurology.org/subscribers/advertise

Neurology ${ }^{\circledR}$ is the official journal of the American Academy of Neurology. Published continuously since 1951, it is now a weekly with 48 issues per year. Copyright @ 2015 American Academy of Neurology. All rights reserved. Print ISSN: 0028-3878. Online ISSN: 1526-632X.

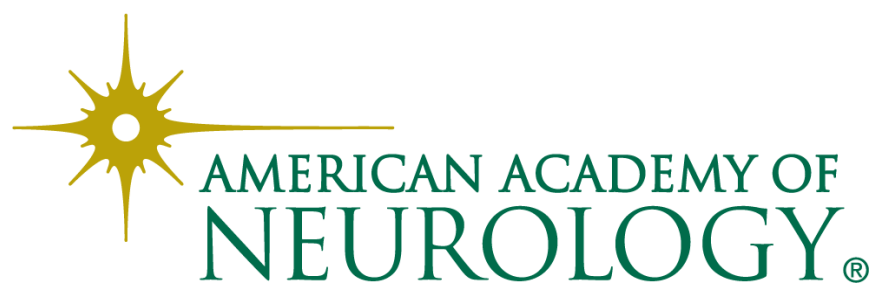

